\title{
Description of the puparium and adult genitalia of Dactylodeictes brevifacies James, 1974 (Diptera: Stratiomyidae)
}

\author{
Lara Duarte Piau Braga ${ }^{1,3}$; Welinton Ribamar Lopes ${ }^{2,4}$ \& José Roberto Pujol-Luz ${ }^{1,5}$ \\ 1 Universidade de Brasília (UNB), Instituto de Ciências Biológicas, Departamento de Zoologia. Brasília, DF, Brasil. \\ ${ }^{2}$ Universidade Federal de Goiás (UFG), Instituto de Ciências Biológicas, Departamento de Ecologia. Goiânia, G0, Brasil. \\ ${ }^{3}$ ORCID: http://orcid.org/0000-0002-7318-2840. E-mail: laradbraga@gmail.com \\ ${ }^{4}$ ORCID: http://orcid.org/0000-0003-1316-2773. E-mail:welintonbio@gmail.com \\ ${ }^{5}$ ORCID: http://orcid.org/0000-0002-8621-4856. E-mail:jrpujolluz@gmail.com
}

\begin{abstract}
The puparium of Dactylodeictes brevifacies was described based on fifty-eight specimens reared in laboratory until the emergence of adults. Larvae were collected under the bark of fallen trees in a Cerrado vegetation, Gallery forest; Palm swamp (Vereda) and open grassland (Campo Limpo) in States of Goiás and Tocantins, Brazil (New Record). The puparium was compared with that of Brachyodina lopesi, the most closely related species with a described puparium. Despite this species clearly shared the larval pachygastrinae features it has a remarkable character not know before for this subfamily: the presence of four pairs of ventral setae (V) in the eighth abdominal segment in ventral view, while in other larvae and puparia of this subfamily, there are five pairs of ventral setae. The adult male and female were described and figured.
\end{abstract}

Key-Words. Brazil; Cerrado Bioma; Neotropical region; Pachygastrinae; Taxonomy.

\section{INTRODUCTION}

The family Stratiomyidae has 12 subfamilies and more than 2.800 species described in the world, distributed in 378 genera (Woodley, 2001, 2011). Woodley (2001) and Pujol-Luz \& Pujol-Luz (2014) asserted that the Neotropical Region has the highest Stratiomyidae diversity, both in relation to the number of genera and the number of species. In this region, 167 genera and approximately 1.000 species were recorded (Woodley, 2001, 2011; Fachin et al., 2016).

Pachygastrinae is one of the largest subfamilies of Stratiomyidae with approximately 600 species in the world (Woodley, 2001, 2011). However, less than 50 species had their larvae or puparia known (Bučánková et al., 2009) and, in the Neotropics, this number decreases to 18 species (Table 1). According to Bučánková et al. (2009) the known larvae of pachygastrines can be recognized by the following combination characters: (1) anal segment rounded posteriorly as in other terrestrial larvae, (2) posterior spiracular opening usually placed dorsally (with a few exceptions), without any pinnate float hairs, (3) subapical sensilla on antenna usually absent (but distinct in Pegadomyia), (4) setae CF2 and V2 on head inserted far before eye prominence, (5) lateral seta on head placed close to anterior margin of eye, (6) marginal setae of body segments considerably elongate in many species (though not in all), (7) elongate or rounded sternal patch confined to abdominal segment 6, (8) five ventral setae on anal segment, (9) arboreal mode of life (under the bark of trees) distinctly predominating in the known larvae.

The genus Dactylodeictes Kertész, 1914 has three species: D. amazonicus Kertész, 1914 (Brazil); D. brevifacies James, 1974 (Panama and Peru) and D. medius James, 1974 (Ecuador and Peru) (Woodley, 2001, 2014). None of these species had their larvae/puparium described yet. Here we described the puparium of $D$. brevifacies based on fifty-eight specimens (34 males and 24 females) that emerged in laboratory conditions. The adults that emerged from these puparia fit perfectly the ones described by James (1974). In addition to the description of the puparium, we registered for the first time the occurrence of this species in Brazil, updating the distribution map and describing male and female terminalia.

\section{MATERIAL AND METHODS}

Larvae of $D$. brevifacies were collected individually under the bark of fallen trees in cities 
Table 1. Neotropical list of known larvae of Pachygastrinae (Mod. de Bučánková, 2009).

\begin{tabular}{|c|c|c|}
\hline Species & Author & Distribution \\
\hline Brachyodina lopesi (Lindner, 1964) * & Xerez et al., 2002 & From Mexico to Brazil \\
\hline Chalcidomorphina aurata Enderlein, 1914 & Pujol-Luz \& Xerez, 1999 & From Mexico to Peru and Brazil \\
\hline Chlamydonotum nigreradiatum Lindner, 1949 & Xerez \& Garcia, 2008 & Argentina, Brazil \\
\hline Chorophthalmyia brevicornis Lindner, 1964 & Pujol-Luz et al., 2016 & Brazil, Costa Rica \\
\hline Cosmariomyia argyrosticta Kertész, 1914 & Xerez et al., 2002 & Argentina, Brazil, Costa Rica, El Salvador \\
\hline Dactylodeictes brevifacies James, 1974 & This paper & Brazil, Panama, Peru \\
\hline Eidalimus henshawi (Malloch, 1917) & Kraft \& Cook, 1961 & Cuba, Mexico \\
\hline Engicerus major Lindner, 1964 & Xerez et al., 2003a & Brazil \\
\hline Eupachygaster alexanderi (Brèthes, 1922) & Blanchard, 1923 & Argentina \\
\hline Gowdeyana punctifera (Malloch, 1915) & Kraft \& Cook, 1961 & Mexico \\
\hline Manotes crassimanus James, 1980 & Lopes et al., 2006 & Brazil, Mexico \\
\hline Manotes plana Kertész, 1916 & Xerez \& Lopes, 2009 & Argentina, Bolívia, Brazil, Costa Rica, Mexico, Paraguai \\
\hline Pedinocera longicornis Kertész, 1909 & Lopes et al., 2006 & Brazil, Peru \\
\hline Popanomyia femoralis Kertész, 1909 & Xerez et al., 2003a & Brazil, Panama, Peru \\
\hline Popanomyia kerteszi James \& Woodley, 1980 & Marques \& Xerez, 2009 & Brazil, Panama, Peru \\
\hline Psephiocera modesta (Lindner, 1949) & Xerez et al., 2003b & Brazil \\
\hline Vittiger schnusei Kertész, 1909 & Xerez \& Pujol-Luz, 2001 & Brazil, Peru \\
\hline Zabrachia magnicornis Cresson, 1919 & James, 1965 & Mexico \\
\hline Zabrachia stoichoides James, 1965 & James, 1965 & Mexico \\
\hline
\end{tabular}

* Former Dactylodeictes lopesi (Lindner, 1964)

of Alvorada, Varjão and Goiânia, State of Goiás, and city Peixes, State of Tocantins, Brazil (Fig. 1). They were reared in separate Petri dishes containing substrate (rotting wood and pieces of bark) from the original locale until the emergence of adults. The fifty-eight adults emerged in the laboratory. The adults were mounted on entomological pins (Figs. 2-3) and the puparia were conditioned in microtubes. The material (adults and puparia) were housed in the Entomological collection of the Departamento de Zoologia, Universidade de Brasília (DZUB), Distrito Federal and Zoological collection of the Departamento de Ecologia, Universidade Federal de Goiás (CZUFG), State of Goiás, Brazil.

The keys of Woodley (2009), James (1974), James et al. (1980) and the original description of D. brevifacies James (1974) were used for identification of adults. Male and female terminalia were treated with lactic acid in water-bath for 30 minutes, dissected and temporarily mounted in concave slides with glycerin. The terminalia were preserved in a microvial with glycerin. Photos were taken with Leica DFC295 ${ }^{\circ}$ camera coupled to a Leica ${\mathrm{M} 205 \mathrm{C}^{\odot} \text { stereomicroscope and Leica DM2000 }}^{\circ}$ microscope and measurements $(\mathrm{mm})$ were taken using the LAS-V3-8 ${ }^{\circ}$ software.

The preparation of the puparia for Scanning Electron Microscopy (SEM) was as it follows: After cleaning the puparia, they were preserved in $70 \%$ ethanol, dehydrated in a graded series of ethanol solution and dried by the critical point technique with $\mathrm{CO} 2$. Dried specimens were mounted on stubs, coated with palladium gold and observed under JEOL JSM $7001 \mathrm{~F}^{\odot}$ scanning electron microscope.

The terminology adopted in the description of the puparia, including the chaetotaxy follows Rozkošný (1982). To describe terminalia we used Sinclair et al. (1994). The following abbreviations were used: (a) anten- na; (Ad) anterodorsal setae; (Ap) apical setae; (as) anterior spiracle; (bs) basal segment; (cerc) cerci; (Cf) clypeofrontal setae; (D) dorsal setae; (DI) dorsolateral setae; (e) eye; (epand) epandrium; (goncx) gonocoxites; (goncx apod)

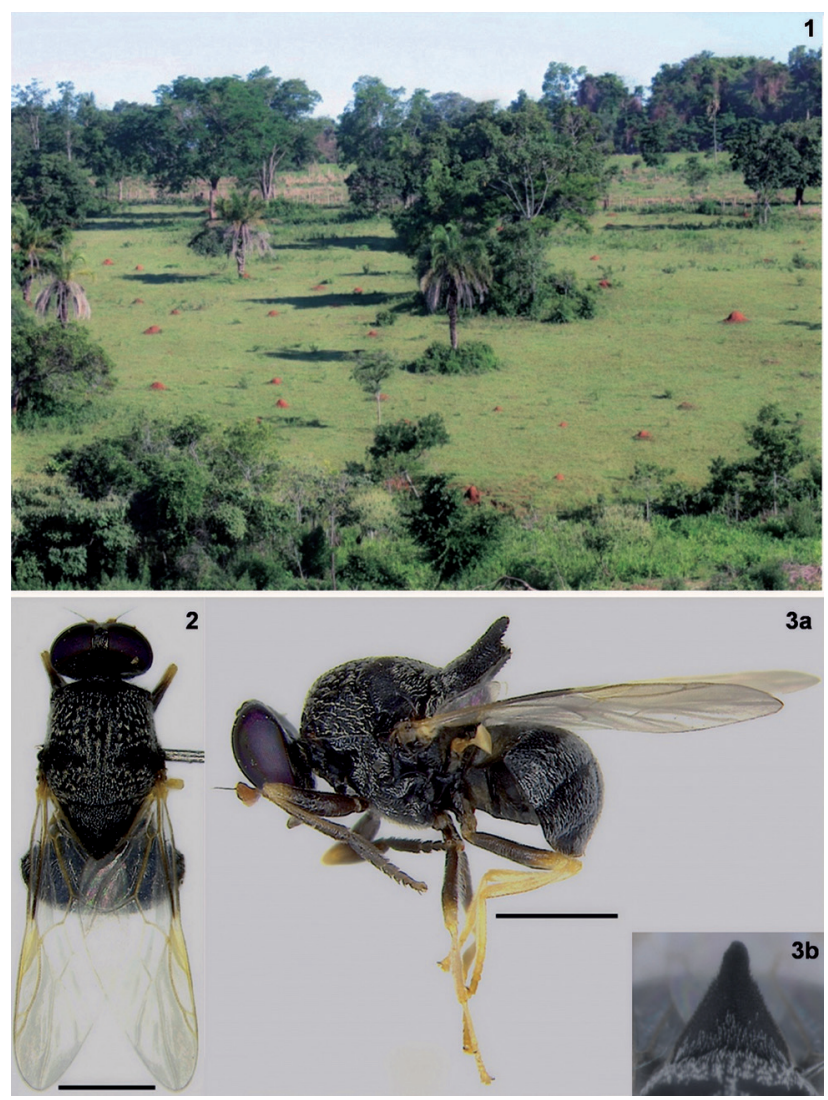

Figures 1-3. (1) Site of collection in the Cerrado vegetation City of Varjão, State of Goiás, Brazil. (2) Dactylodeictes brevifacies. Male in dorsal view. Scale bar = $100 \mu \mathrm{m}$. (3) Dactylodeictes brevifacies. (A) Male in lateral view; (B) Scutellum in dorsal view. Scale bar $=100 \mu \mathrm{m}$ (Fig. 3a). Scale bar $=200 \mu \mathrm{m}$ (Fig. 3b). 


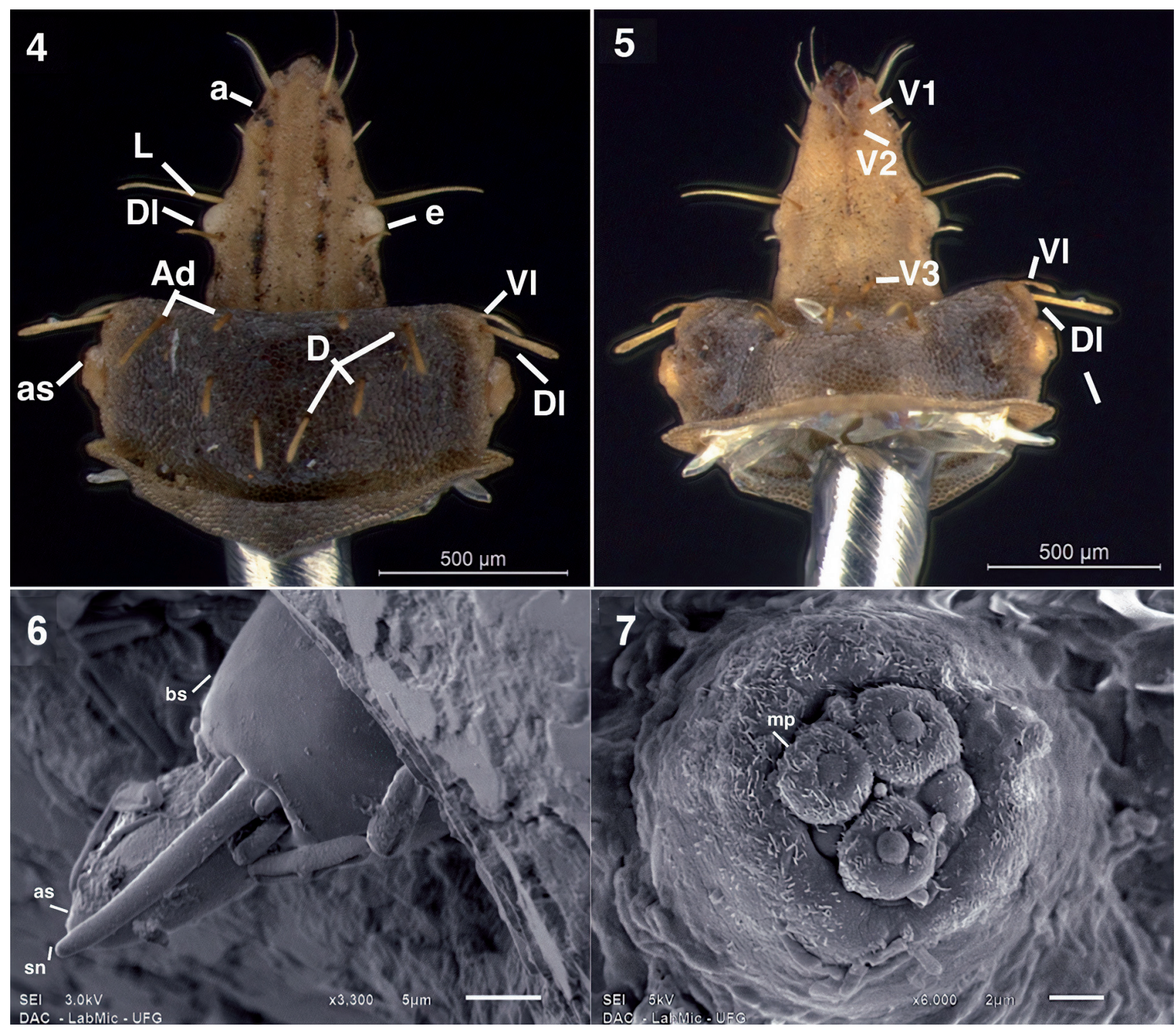

Figures 4-7. Dactylodeictes brevifacies. Puparia. (4) Head and first thoracic segment (dorsal view); (5) Head and first thoracic segment (ventral view); (6) Antennae; (7) Maxillary palpus. Scale bar $=500 \mu \mathrm{m}$ (Figs. 4-5). Scale bar $=5 \mu \mathrm{m}$ (Fig. 6). Scale bar $=2 \mu \mathrm{m}$ (Fig. 7).

gonocoxal apodeme; (gonst) gonostyles; (hypd) hypandrium; (L) lateral setae; (mp) maxillary palpus; (pb) posterior bridge; (pp) posterolateral process; (sn) sensilla; (Sa) subapical setae; (sp) sternal patch; (V) ventral setae and (VI) ventrolateral setae.

\section{RESULTS}

\section{Dactylodeictes brevifacies James, 1974}

Records of geographical distribution: Neotropical: Panama, Peru (Madre de Dios, Avispas), Brasil: (Goiás e Tocantins) new record.

Material examined: Fifty-eight puparia (34 $0^{7} 0^{\pi}$ and 24 ९९): Brasil, Goiás, Alvorada, 09.iii.2004, J. Brandão col. (DZUB), emerged 29.ix.2004 (2 \%क), 11.x.2004 (2 우); Goiânia, Campus Samambaia-UFG, 12.xii.2016, W.R. Lopes col. (CZUFG), emerged 25.viii.2017 (1 $\left.\sigma^{7}\right)$, 07.ix.2017 (1 \$), 26.ix.2017 (1 ơ); Varjão, 18.xii.2016, W.R. Lopes col. (CZUFG), emerged 09.viii.2017 (1 o'), 05.ix.2017 (1 \&), 07.ix.2017 (1 ơ), 09.ix.2017 (1 \&), 11.ix.2017 (1 \&), 19.ix.2017 (1 \$), $01 . x .2017$ (1 ठో), 09.x.2017 (1 \$), 24.x.2017 (1 ९), emerged 20.xii.2017 (1 ९); Varjão, 21.i.2017, W.R. Lopes col. (CZUFG), emerged 09.viii.2017 (1 \$), emerged

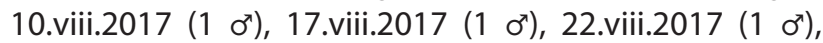
28.viii.2017 (2 \&o), 28.viii.2017 (1 ه'), 30.viii.2017 (2 \&o), 31.viii.2017 (1 $\left.\sigma^{7}\right), 04 . i x .2017$ (1 \&), 29.x.2017 (1 $\left.\sigma^{7}\right)$,

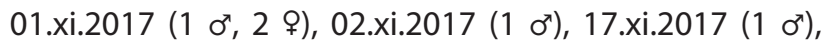
08.xii.2017 (1 $\left.\sigma^{\top}\right)$, 27.xii.2017 (1 \$); Varjão, 28.ii.2017, W.R. Lopes col. (CZUFG), emerged 26.viii.2017 (1 $\left.\sigma^{7}\right)$, 15.x.2017 (1 \&), 16.x.2017 (1 \&), 26.x.2017 (1 \&), 30.x.2017 (2 우), 01.xi.2017 (2 우), 01.xi.2017 (1 ơ), 02.xi.2017 (1 o'), 22.xi.2017 (1 ९); Goiânia, Campus Samambaia-UFG, W.R. Lopes col. (CZUFG), 29.iii.2017, emerged 13.ix.2017 (1 \$); 30.iii.2017, emerged 11.ix.2017 (1 \$), 30.x.2017

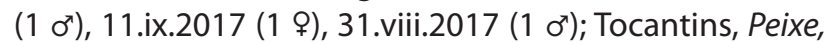
25.iv.2018, W.R. Lopes col. (CZUFG), emerged 07.xi.2018 (1 ơ), 29.xi.2018 (1 ᄋ), 28.i.2019 (1 o'). 


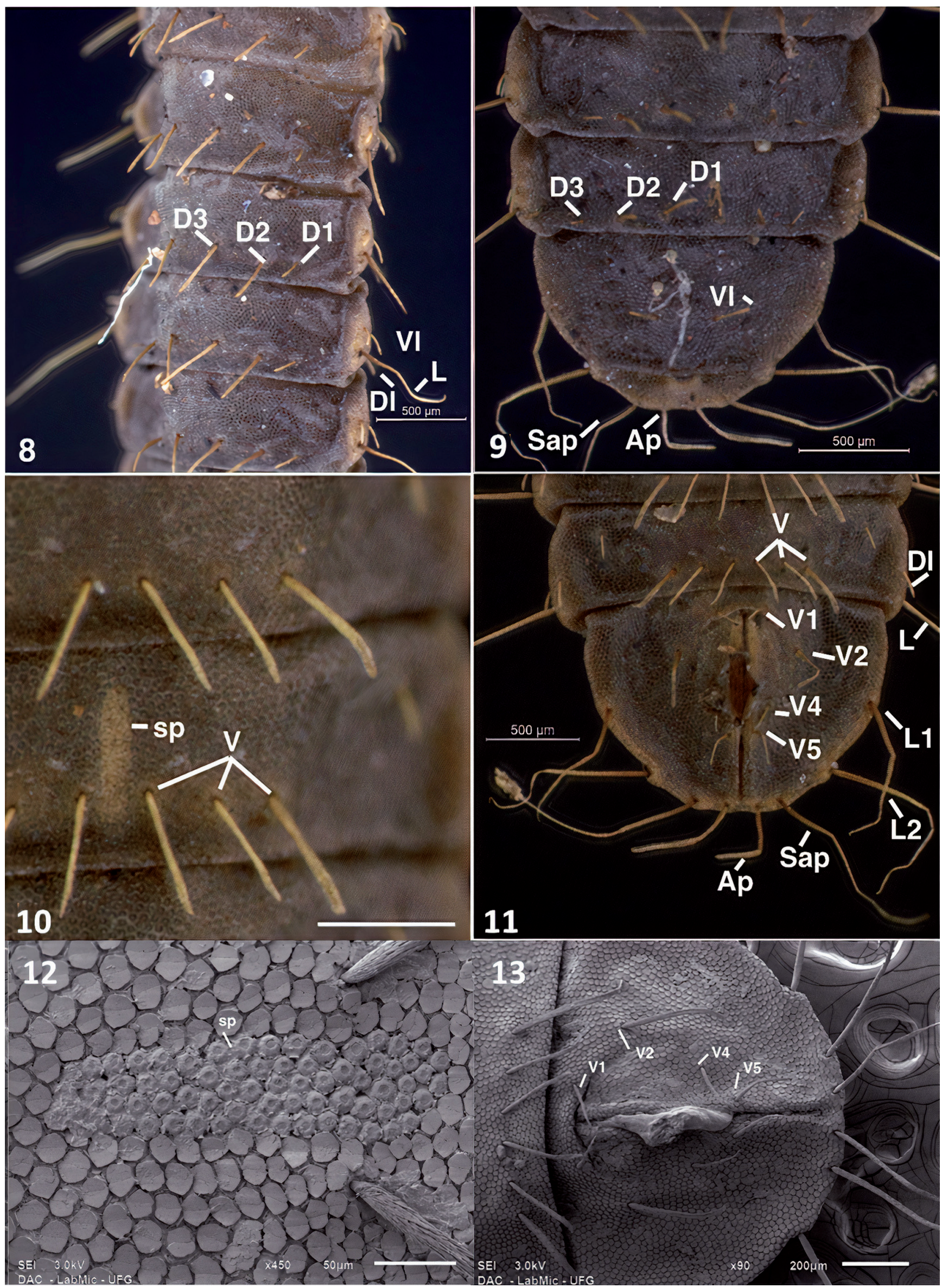

Figures 8-13. Dactylodeictes brevifacies. Puparia. (8) Structure of the bristles of the lateral region of the abdominal segments; (9) Abdominal segments (dorsal view); (10) Sixth abdominal segment; (11) Abdominal segments (ventral view); (12) Sternal patch on abdominal segment 6, in ventral view; (13) Abdominal segment 8 in ventral view. Scale bar $=500 \mu \mathrm{m}$ (Figs. 8-9). Scale bar $=200 \mu \mathrm{m}$ (Fig. 10). Scale bar $=500 \mu \mathrm{m}$ (Fig. 11). Scale bar $=50 \mu \mathrm{m}$ (Fig. 12). Scale bar $=200 \mu \mathrm{m}$ (Fig. 13). 
Puparium: Length 7.2-7.8 $\mathrm{mm}$, body flattened dorsoventrally with head, three thoracic segments, and eight abdominal. Cuticle with usual mosaic appearance. Chromatic pattern dark yellowish-brown. Plumose setae.

Head: Triangular and not dorsoventrally flattened; length slightly larger than the width (Figs. 4-5). In the anterior part of the head, presence of a small antenna with four sensilla, the third much longer than others (Fig. 6; maxillary palpus ( $\mathrm{mp}$ ) with three sensory papillae rounded at apex (Fig. 7). Chaetotaxy: one pair of lateral setae (L) inserted posteriorly to the antenna (a) and ventrally to the eyes (e); two pairs of clypeofrontal setae (Cf) (antenna inserted between the $1^{\text {st }}$ and $2^{\text {nd }}$ pair), dorsolateral setae (DI) at the height of the final portion of the eye (e) (Fig. 4); three pairs of ventrolateral setae (VI) and three pairs of ventral setae (V) (Fig. 5).

Thorax: First segment narrower (horizontally) than the other segments and taller (vertically) than the next segment; anterior spiracle (as) prominent with a pair of dorsolateral setae (DI) and a pair of ventrolateral setae
$(\mathrm{VI})$ above; first segment in dorsal view with two rows of bristles: two pairs of anterodorsal setae (Ad) and three pairs of dorsal setae (D). In ventral view, two pairs of ventral setae $(\mathrm{V})$, the outermost pair being bifurcated (Figs. 4-5); $2^{\text {nd }}$ and $3^{\text {rd }}$ segments with a row with three pairs of dorsal setae (D); two pairs of ventral setae (V), the outermost pair being bifurcated in the $2^{\text {nd }}$ and $3^{\text {rd }}$ segments; a pair of lateral setae (L) and a pair of ventrolateral setae $(\mathrm{VI})$.

Abdomen: Segments 1-7 with basically the same shape; presence of a row with three pairs of dorsal setae (D) (Figs. 8-9), growing as they move away from the center of the body; three pairs of ventral setae (V) (Figs. 10-11), the outer pair being slightly longer than the others; four pairs of lateral abdominal setae (L) - one dorsolateral pair (DI), one lateral pair (L), two ventral pairs (V) (Fig. 8); ventromedial line of the sixth segment with a characteristic uniform elliptic sternal patch (sp) (Figs. 10 and 12), the base of the inner ventral setae $(\mathrm{V})$ more distant than in other segments; segment 8 apically rounded, with a pair of dorsal setae; four pairs of ventral setae (V)
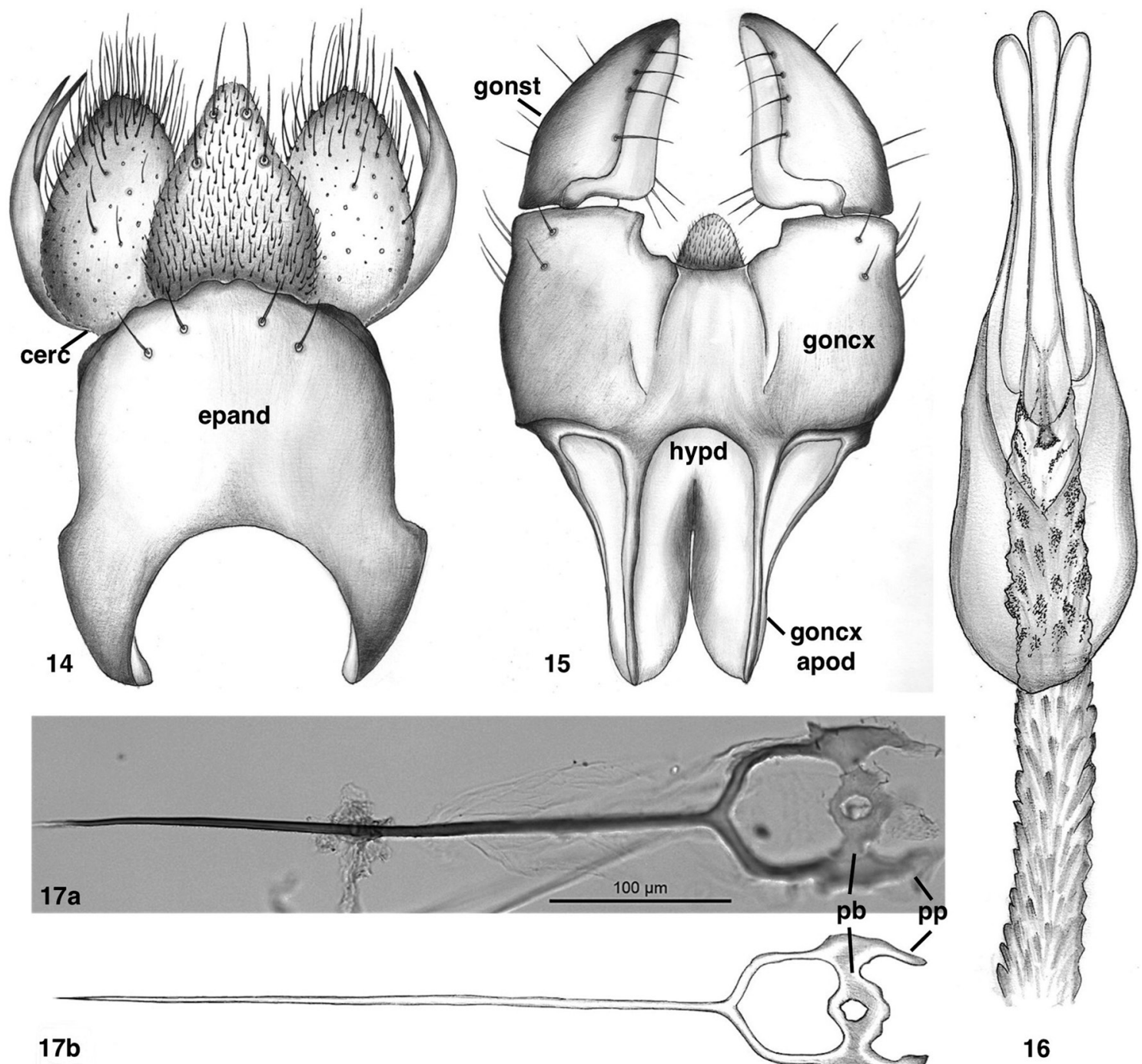

17b

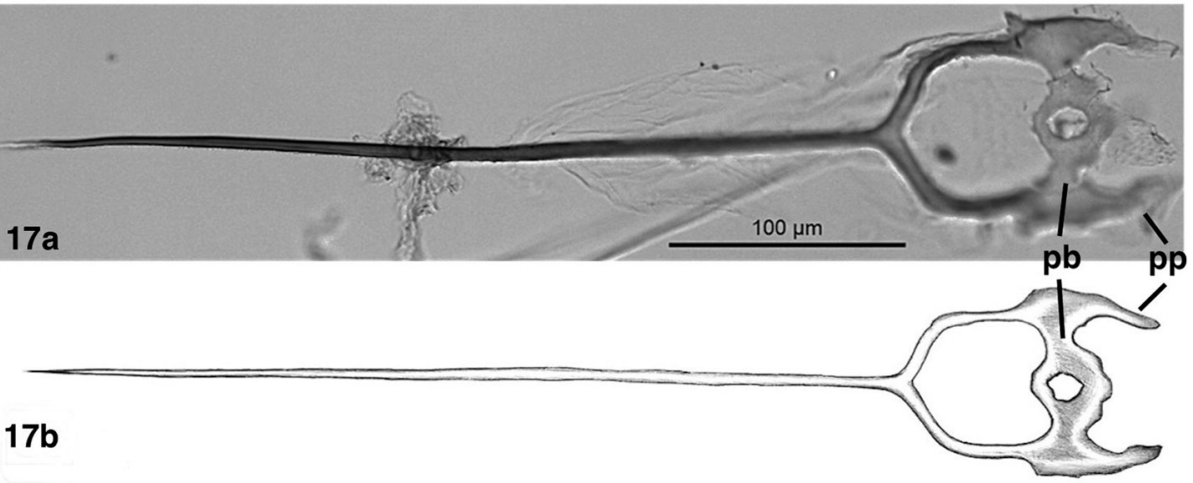

16

Figures 14-17. Dactylodeictes brevifacies. Male: (14) epandrium (tergite 9), tergite 10 and cerci, in dorsal view; (15) hypandrium, gonocoxites and gonostyles, dorsal view; (16) aedeagus trifid; Female: (17) genital fork. (A) genital fork optical microscopy; (B) schematic representation draw of genital fork. 
(Figs. 11 and 13); two pairs of lateral setae (L), the second pair inserted more dorsally and not facing downwards, a pair of subapical setae (Sap) and a pair of apical setae (Ap).

Male adult terminalia: Epandrium semi-rectangular; proctiger (hypoproct) subtriangular; cerci (cerc) margined with long bristles and bifid spine-like epandrial (Fig. 14); hypandrium (hypd) sub rectangular in dorsal view; gonocoxite (goncx) quadrangular, with gonocoxal apodeme (goncx apod) parallel and rounded ends; posterior margin of the hypandrium is short and arched; gonostyle (gonst) simple, rounded, concave medially (spoon shaped) and arched toward the midline (Fig. 15); aedeagus trifid large with the distal half; lobes of the aedeagus free, projected beyond the distal end of gonocoxite (Fig. 16).

Female adult terminalia: Tergite 9 rounded, wider distally than basally. Genital fork with posterior arm subigual than anterior arm (Fig. 17a-17b); anterior arm arched with an extremely long and thin process; posterior bridge (pb) with a medial orifice, posterolateral process (pp) broader posteriorly. Cercus with only one segment.

\section{TAXONOMIC NOTES}

The larvae and puparia of $D$. brevifacies can be identified by the following combination of characters: (1) the first thoracic segment with two rows of setae; (2) two pairs of anterodorsal setae and three pairs of dorsal setae, the third pair of dorsal setae (D3) is longer than the other two pairs of dorsal setae; (3) the sternal patch with elliptical shape in the sixth abdominal segment; (4) the base of the first pair of ventral setae (V1) of the sixth abdominal segment, are more distant than in other segments and (5) the eighth abdominal segment has four pairs of ventral setae. The four pairs of ventral setae (V) in the segment eight of larvae and puparia of D. brevifacies was neither observed nor keyed in Rozkošný (1982) nor Pujol-Luz \& Pujol-Luz (2014). These authors keyed the Pachygastrinae as having five pairs of setae. The discovery of the immature forms of $D$. brevifacies modifies the Pachygastrinae couplets in the identification keys, update to the presence of 4-5 ventral setae in the eighth segment.

\section{ACKNOWLEDGMENTS}

This research was developed with grants from the Conselho Nacional de Desenvolvimento Científico e Tecnológico (CNPq) and Coordenação de Aperfeiçoamento de Pessoal de Nível Superior (CAPES). We thank Ivan Konstantinov Malinov for the final artwork. To Alexandre Ariel da Fonseca de Souza, Fernando Magela de Jesus and Dr. Martin Hauser (CDFA) for reading the manuscript and making helpful comments and suggestions.

\section{REFERENCES}

Blanchard, E.E. 1923. Apuntes sobre dos dípteros argentinos. Physis, 6: 319-323.

Bučánková, A.; Kovac, D. \& Rozkošný, R. 2009. The larva and puparium of the Oriental Pegadomyia pruinosa Kertész, with a world list of the described Pachygastrinae larvae (Diptera: Stratiomyidae). The Raffles Bulletin of Zoology, 57: 339-249.

Fachin, D.; Couri, M. \& Mello-Patiu, C. 2016. An illustrated catalogue of the types of Stratiomyidae (Diptera: Brachycera) in the collection of Museu Nacional, Rio de Janeiro, Brazil. Zootaxa, 4084: 361-376.

James, M.T. 1965. Contributions to our knowledge of the Nearctic Pachygasterinae (Diptera: Stratiomyidae). Annals of the Entomological Society of America, 58(6): 902-908.

James, M.T. 1974. The Pachygastrine genera Dactylodeictes, Chalcidomorphina, and Thopomyia in South America (Diptera, Stratiomyidae). Melanderia, 14: 23-32.

James, M.T.; Mcfadden, M. \& Woodley, N. 1980. The Pachygastrinae (Diptera, Stratiomyidae) of Middle America. Melanderia, 34: 1-36.

Kraft, K.J. \& Cook, E.F. 1961. A revision of the Pachygasterinae (Diptera, Stratiomyidae) of America North of Mexico. Miscellaneous Publications of the Entomological Society of America, 3: 1-24.

Lopes, A.L. de F.; Xerez, R. de; Silva, R.R. da \& Pujol-Luz, J.R. 2006. Descrição dos pupários de Manotes crassimanus James e Pedinocera longicornis Kertész (Diptera, Stratiomyidae, Pachygastrinae) da Ilha da Marambaia, Mangaratiba, Rio de Janeiro, Brasil. Revista Brasileira de Zoologia, 23(3): 733-739.

Marques, K.I. de S. \& Xerez, R. de. 2009. Descrição da Larva de Popanomyia kerteszi James \& Woodley (Diptera: Stratiomyidae) e Chave de Identificação para os Estágios Imaturos de Pachygastrinae. Neotropical Entomology, 38: 643-648.

Pujol-Luz, J.R. \& Pujol-Luz, C.V.A. 2014. Stratiomyidae, In: Roig-Juñent, S.; Claps, L.E. \& Morrone, J.J. (Directores). Biodiversidad de Artrópodos Argentinos. San Miguel de Tucumán, Editorial INSUE-UNT. Argentina, v. 3, p. 399-406.

Pujol-Luz, J.R. \& Xerez, R. de. 1999. The larva of Chalcidomorphina aurata Enderlein 1914 (Diptera: Stratiomyidae) from Ilha da Marambaia, Rio de Janeiro, Brasil. Proceedings of the Entomological Society of Washington, 101: 295-299.

Pujol-Luz, J.R.; Lopes, W.R. \& Viana, G.G. 2016. Description of the puparium and redescription of the imagoes of Chorophthalmyia brevicornis Lindner (Diptera: Stratiomyidae). Zootaxa, 4121: 583-588.

Rozkošný, R. 1982. A biosystematic study of the European Stratiomyidae (Diptera), vol. 1. Introduction Beridinae, Sarginae, Stratiomynae. The Hague, Dr. W. Junk. 401p.

Sinclair, B.J.; Cumming, J.M. \& Wood, D.M. 1994. Homology and phylogenetic implications of male genitalia in Diptera-Lower Brachycera. Entomologica Scandinavica, 24: 407-432.

Woodley, N.E. 2001. A world catalogue of the Stratiomyidae (Insecta: Diptera). Myia, 11: 1-475.

Woodley, N.E. 2009. Stratiomyidae, In: Brown, B.V.; Borkent, A.; Cumming, J.M.; Wood, D.M.; Woodley, N.E. \& Zumbado, M.A. (Eds.). Manual of Central American Diptera, vol. 1. Ottowa, NRC Research Press. p. 521-550.

Woodley, N.E. 2011. A World Catalog of the Stratiomyidae (Insecta: Diptera): A supplement with revisionary notes and errata. Myia, 12: 379-415.

Woodley, N.E. 2014. Two new species of Brachyodina Lindner from the Caribbean with a key to species of the genus from the region (Diptera: Stratiomyidae: Pachygastrinae). Proceedings of the Entomological Society of Washington, 116: 429-440. 
Xerez, R. de \& Garcia, E.R. 2008. Description of the Puparium of Chlamydonotum nigreradiatum Lindner (Diptera: Stratiomyidae) from Ilha da Marambaia, Mangaratiba, RJ, Brazil. Neotropical Entomology, 37(5): 567-570.

Xerez, R. de \& Lopes, A.L.F. 2009. Description of the puparium of Manotes plana (Diptera: Stratiomyidae: Pachygastrinae) from the Ilha da Marambaia, Mangaratiba, state of Rio de Janeiro, Brazil. Zoologia, Curitiba, 26: 575-577.

Xerez, R. de \& Pujol-Luz, J.R. 2001. Description of the larva of Vittiger schnusei Kertész, 1909 (Diptera: Stratiomyidae) from Ilha da Marambaia, Rio de Janeiro, Brazil. Studia Dipterologica, 8: 337-341.
Xerez, R. de; Pujol-Luz, J.R. \& Viana, G.G. 2002. Descrição da larva de Cosmariomyia argyrosticta Kertész e do pupário de Dactylodeictes lopesi Lindner (Diptera, Stratiomyidae). Revista Brasileira de Zoologia, 19: 747-755.

Xerez, R. de; Pujol-Luz, J.R. \& Viana, G.G. 2003a. Descrição da larva de Popanomyia femoralis Kertész, 1909 a do pupário de Engicerus major Lindner, 1964 (Diptera, Stratiomyidae). Revista Brasileira de Entomologia, 47: 7474-755

Xerez, R. de; Pujol-Luz, J.R. \& Viana, G.G. 2003b. Description of the larva of Psephiocera modesta (Lindner, 1949) (Diptera: Stratiomyidae: Pachygastrinae). Studia Dipterologica, 10: 189-193. 